\title{
Calcium partition in Minas Padrão cheese and its bioaccessibility during ripening time
}

\author{
João Pablo Fortes PEREIRA ${ }^{1}$, Ana Carolina MAGESTE ${ }^{1}$, Náira da Silva CAMPOS², Rafael Arromba de SOUSA², \\ Júlia d'Almeida FRANCISQUINI ${ }^{3}$, Ítalo Tuler PERRONE ${ }^{3 *}$, Antônio Fernandes de CARVALHO ${ }^{3}$, \\ Renato Moreira NUNES ${ }^{1}$, Marta Fonseca MARTINS ${ }^{4}$ (D), Paulo Henrique da Fonseca da SILVA ${ }^{1}$
}

\begin{abstract}
Nutritionally, cheese and other dairy products have been highlighted especially as a calcium source. Access to minerals is dependent on variables related to diet, lifestyle, and also the health status. This study aimed to evaluate the bioaccessibility and calcium partition in Minas Padrão cheese over its ripening period for experimentally obtained samples. The cheese of the study has been manufactured using two different technologies (A and B). Also to evaluate the evolution of pH over cheese ripening and the influence of calcium partitions in its bioaccessibility along the cheese ripening period. The mean values found for total calcium content were $\left(549 \mathrm{mg} \cdot 100 \mathrm{~g}^{-1}-\mathrm{A}\right.$ and $\left.644 \mathrm{mg} \cdot 100 \mathrm{~g}^{-1}-\mathrm{B}\right)$. For calcium in the aqueous phase on average $460 \mathrm{mg} \cdot 100 \mathrm{~g}^{-1}-\mathrm{A}$ and $404 \mathrm{mg} \cdot 100 \mathrm{~g}^{-1}-\mathrm{B}$. These and other changes found are possibly due to physicochemical and biochemical changes, especially with respect to $\mathrm{pH}$ variations. Calcium bioaccessibility decreased in the beginning and then incresed in the end of the ripening period. The results obtained in this work hopefully may allow further studies and the development of products in which calcium bioaccessibility might be indicated on the product's label accordingly to its ripening time.
\end{abstract}

Keywords: minerals; cheese; calcium.

Practical Application: Bioaccessibility of calcium in Minas Padrão cheese vary during ripening.

\section{Introduction}

Minas Padrão cheese is a typical cheese from Minas Gerais - Brazil. Improvement of artisanal cheeses produced in Minas Gerais leads to Minas Padrão cheese development and establishment through technologies based in pasteurized milk (Pereira et al., 2018).

According to the Regulation of Industrial and Sanitary Inspection of Products of Animal Origin, Minas Padrão cheese is

[...] cheese of raw or semi-cooked mass obtained by rennet coagulation of the pasteurized milk with the production of a curd, drained, mechanically pressed, salted and ripened mass (Brasil, 2017).

Nutritionally, cheese and other dairy products have been highlighted especially as a calcium source. This mineral is essential for bodily functions such as nerve transmission, blood clotting, muscle contraction, cellular respiration, formation and maintenance of bones and teeth (Santiago-López et al., 2018; Johnson 2017). The calcium found in cheese can be composing complex proteins that form the structure of it; can be spread in the aqueous phase (AP) either freely (solvated ion) or associated with organic and inorganic anions. Physico-chemical characteristics are responsible for the balance among the different forms of presentations of the mineral and therefore directly influencing cheese characteristics mainly the $\mathrm{pH}$. The effect of $\mathrm{pH}$ itself is often difficult to separate from other concomitant disorders such as colloidal calcium phosphate solubilization, changes in the electrical charge on casein, and hydration of the molecules of this protein (Johnson, 2017; Walther et al., 2008; Fox et al., 2000).

Access to minerals is dependent on variables related to diet, lifestyle, and also the health status. It is understood as bioaccessibility "[...] the fraction which is released from its matrix in the gastrointestinal tract and thereby becomes available for absorption via the intestinal bloodstream" (Gropper et al., 2013). The bioaccessibility can be determined experimentally by "in vitro" testing (Fernández-García et al., 2009).

The efficiency of calcium absorption is similar in most foods, except for foods high in oxalates and phytates. (Gropper et al., 2013; Cozzolino, 2010; Martini \& Wood, 2002). Calcium interacts with other nutrients, this factor is also important in bioaccessibility considering the complexity of cheese, this study`s matrix (Pimentel et al., 2018; Silva et al., 2017). Due to the diversity of biochemical reactions resulting from the Minas Padrão cheese ripening process a more detailed study is justifiable on calcium behavior and partitions as well as the bioaccessibility of the mineral over the period of ripening and storing. 
The study aimed to evaluate the bioaccessibility and calcium partition (aqueous phase and free) in Minas Padrão cheese over ripening period, on experimentally obtained samples for two manufacturing technologies. Also to evaluate the evolution of $\mathrm{pH}$ over cheese ripening and the influence of calcium partitions in its bioaccessibility along the cheese ripening period.

\section{Materials and methods}

\subsection{Production of Minas Padrão cheese}

The Minas Padrão cheeses of the study were manufactured in Candido Tostes Dairy Institute - EPAMIG (Juiz de Fora, Minas Gerais, Brazil), using two different technologies, the first (Technology A) without removal of whey and the second (Technology B) with partial withdrawal of whey and addition of warm water during paddling. At the end were performed a total of six fabrications, with three replicates for each technology. The used manufacturing technologies (A) and (B) are described in Figure 1.

To determine the proximate analysis, Fat in Dry Matter (FDM) and calcium attributes in AP (Aqueous Phase), free calcium, cheese $\mathrm{pH}$ and $\mathrm{pH}$ of the AP. To prepare the descriptive analysis the products were examined 28 days after manufacture.

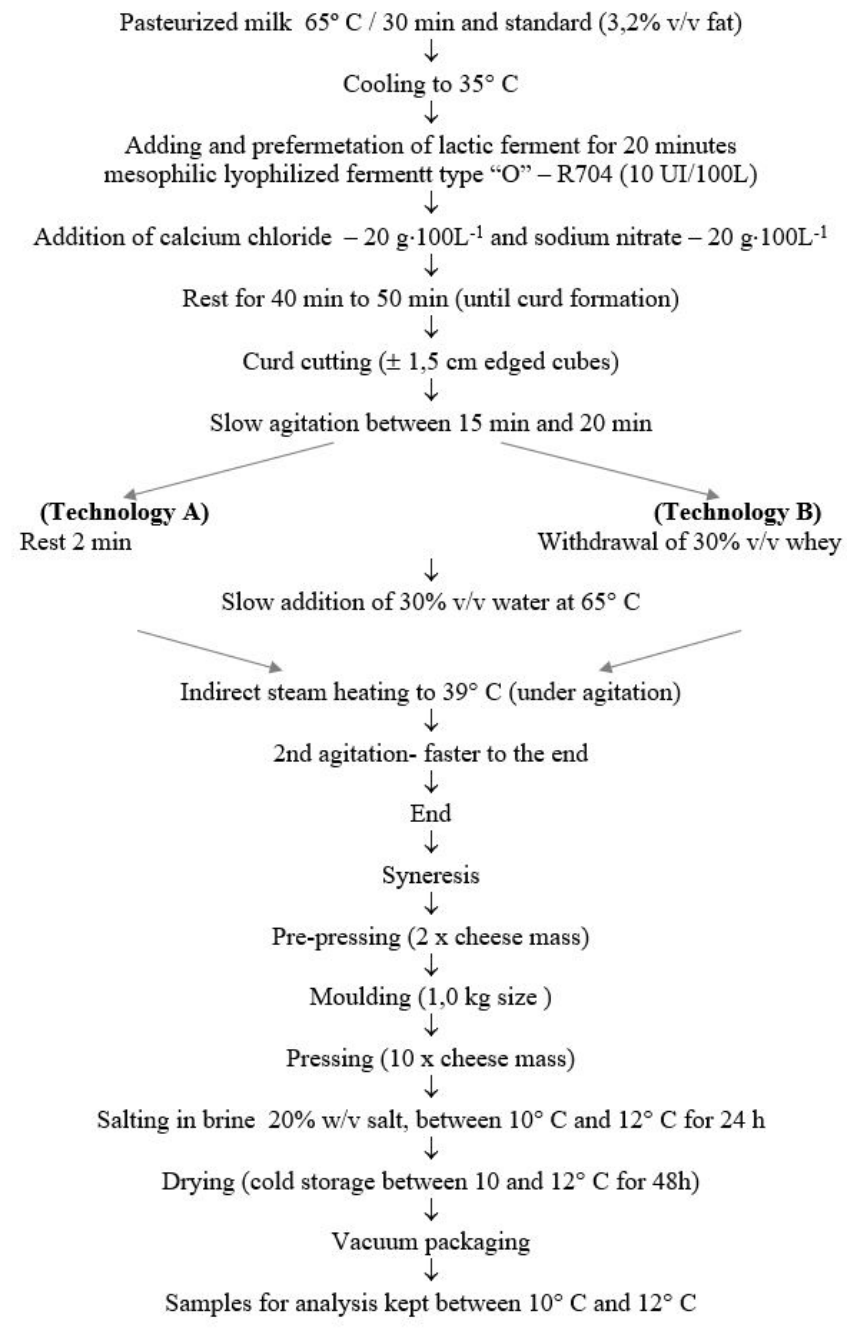

Figure 1. Production flow chart of Minas Padrão cheese.

\subsection{Extraction of aqueous phase}

For extraction of the aqueous phase (AP), the refrigerated products were transported to Viçosa, Minas Gerais, Brazil, where at the laboratory - INOVALEITE at Federal University of Viçosa - UFV the extraction was carried out by mechanical pressing of samples following the methodology described by Salvat-Brunaud et al. (1995). This procedure was carried out when the samples were 6, 27, 48 and 69 days old. On the following day for all samples of all ripening times at the Instrumental Analysis Laboratory of Nutrition at Federal University of Juiz de Fora - UFJF (Juiz de Fora, Minas Gerais, Brazil) the extracts were centrifuged at $2990 \times g$ for 5 minutes and filtered through cotton. Thus obtaining the AP for further analysis.

\subsection{Determination of hydrogan potential}

The determination of the hydrogen potential $(\mathrm{pH})$ of cheeses and APs were performed using the $\mathrm{pH}$ meter Gehaka - PG model 1800. Readings were determined with electrode immersion in different points where measurements were taken in cheese samples and in the AP samples whenever these were the object of measurement. Such procedures were performed when the cheeses were 1, 2, 7, 28, 49 and 70 days old. As for APs of cheese $\mathrm{pH}$ measurement occurred when the samples were $7,28,49$ and 70 days old.

\subsection{Determination of calcium}

Samples preparation

The samples were homogenized in a porcelain mortar, (cheeses, $\mathrm{AP}$ and dialysis membranes contents as in 2.6) weighed into porcelain crucibles $(\sim 100 \mathrm{mg})$ and calcined at $550{ }^{\circ} \mathrm{C}$ for $16 \mathrm{~h}$. The obtained residue (ash) was resuspended with nitric acid solution of $2 \% \mathrm{v}^{\cdot} \mathrm{v}^{-1}$, quantitatively transferred to a volumetric flask and the volume measured to $25.00 \mathrm{~mL}$ with deionized water. This procedure was performed in triplicate.

\section{Analytical determination}

After opening, the total calcium levels were determined in samples by Flame Atomic Absorption Spectrometry (FAAS) in the Department of Chemistry at UFJF. The spectrometer analyzes were performed on Thermo Scientific, model SOLAAR M5 in accordance with the following instrumental conditions: nitrous oxide - acetylene flame with a flow of $4.2 \mathrm{~L} \cdot \mathrm{min}^{-1}$ of acetylene, burner height of $11 \mathrm{~mm}$; wavelength of $422.4 \mathrm{~nm}$ at $\pm 0.5 \mathrm{~nm}$ scan and readings in triplicates. For calibration of the equipment it has been used standard calcium solution (Ultra Scientific, Kingstown, USA) with concentrations ranging from $1.00 \mathrm{mg} \cdot \mathrm{L}^{-1}$ to $7.00 \mathrm{mg} \cdot \mathrm{L}^{-1}$. Calcium levels were determined during four periods of ripening $(7,28,49$ and 70 days old).

\subsection{Determination of free calcium}

The determination of free calcium was performed in the cheese AP by ion selective electrode for calcium - Orion 4-STAR with the reading performed directly by immersing the electrode 
in the cheese AP. There were free calcium measurements over the four ripening periods (7, 28, 49 and 70 days old).

\subsection{Determination of calcium bioaccessibility}

Bioaccessibility was determined according Luten et al. (1996), modified by undergoing $7 \mathrm{~g}$ of crushed cheese to simulated "gastric digestion" with pepsin in hydrochloric acid solution of $0.1 \mathrm{~mol} \cdot \mathrm{L}^{-1}, \mathrm{pH}$ adjusted ranging from 1.7 to 2.0. The mixture was then subject to stirring at $37^{\circ} \mathrm{C}$ for 2 hours. After the simulated digestion it was determined the acidity of digested matter and preparation of the dialysis membrane (Spectra/por ${ }^{\circledR}$ - MWCO model: 12,000 D - 14,000 D), to which were added an equimolar solution of sodium bicarbonate. The membranes were used to simulate enteric digestion of $30 \mathrm{~g}$ of gastric digested under stirring at $37{ }^{\circ} \mathrm{C}$ for 4 hours (enteric digestion). After the mixture reaches a $\mathrm{pH}$ close to 5.0 (approximately 40 minutes), it was added pancreatin and bile extract solution. At the end of 4 hours, the dialysis membrane was removed and the contents underwent determination of present calcium by F AAS - 4.2.2 (1). To obtain the fraction of bioavailable calcium, it was also determined by F AAS - 4.2.2 the total calcium content in cheese after opening of the samples and dissolution in dilute nitric acid (2). Hence, it is possible to determine the percentage of calcium bioaccessibility in cheese by means of equation $\%$ calcium bioaccessibility $=\left[(1) \cdot(2)^{-1}\right] \cdot 100$.

The determinations were carried out during four periods (7, 28, 49 and 70 days of manufacture).

\subsection{Statistical analysis}

Statistical analysis was performed using the statistical software Prism 5.0 (GraphPad, USA). Data on the composition and the calcium partition attributes and cheese $\mathrm{pH}$, calcium bioaccessibility and aqueous phase $\mathrm{pH}$ were evaluated by descriptive analysis, using the results for 28 days of manufacture. Calcium partition, aqueous phase $\mathrm{pH}$ and mineral bioaccessibility were analyzed along four ripening times (7, 28, 49 and 70 days old). In the $\mathrm{pH}$ evaluation besides the above mentioned times, measurements were performed on the day of production (day 1) and the next day (day 2). Two-way analysis of variance (Two-way ANOVA) followed by Bonferroni test for variables with statistically significant parametric distribution was carried out. The significance level for all tests was $\mathrm{p}<0.05$.

\section{Results}

\subsection{Analysis of descriptive statistics for Minas Padrão cheese produced with different manufacturing technologies}

Table 1 presents the chemical composition, fat in the dry matter (FDM), calcium partition (AP calcium and free calcium), bioaccessibility, Minas Padrão cheese $\mathrm{pH}$ and aqueous phase $\mathrm{pH}$ for cheese produced by both technologies.

\subsection{Hydrogen potential}

The taking of averages and two-way analysis of variance followed by Bonferroni test were shown in Figure 2, means distribution shown in Table 2.

\subsection{Calcium in aqueous phase}

The average calcium content in the AP during ripening performed for both technologies, subject to the two-way analysis of variance and Bonferroni test are shown in Figure 3, and the distribution of means shown in Table 3.

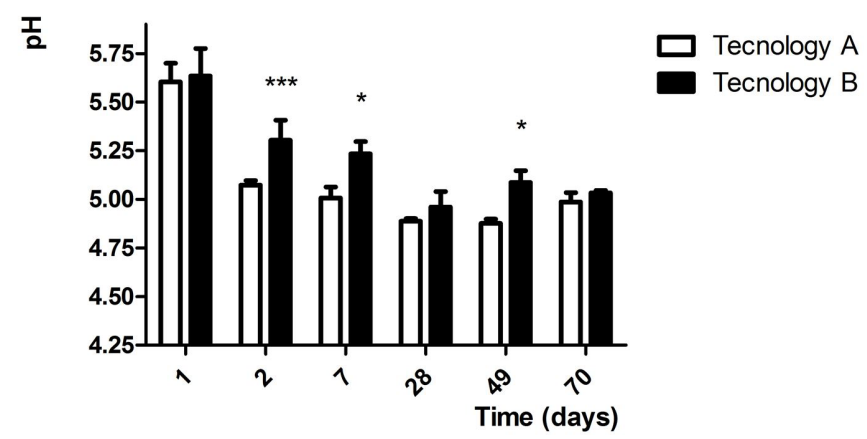

Figure 2. Evolution of $\mathrm{pH}$ during ripening of Minas Padrão cheese for $\mathrm{A}$ and $\mathrm{B}$ followed by Bonferroni's test $\left({ }^{*} \mathrm{p}<0.05\right.$ and $\left.{ }^{* * *} \mathrm{p}<0.001\right)$.

Table 1. Results of attributes in the Minas Padrão cheese produced by both technologies.

\begin{tabular}{|c|c|c|c|c|c|c|c|c|c|c|}
\hline 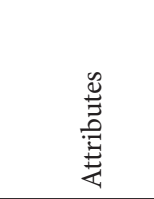 & 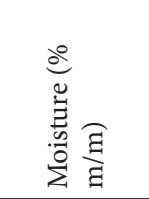 & 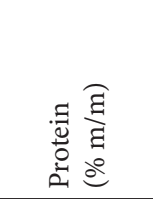 & 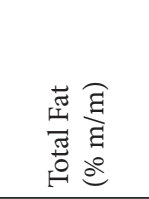 & 主 & 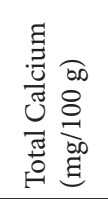 & 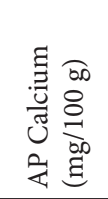 & 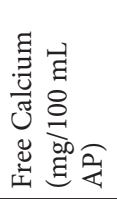 & 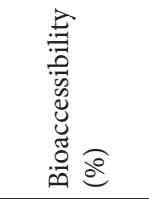 & 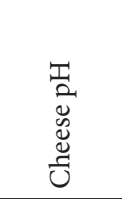 & 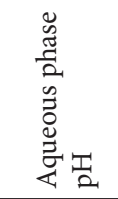 \\
\hline Technology & A B & A B & A B & A B & A B & A B & A B & A B & A B & A B \\
\hline Mean & 48.5049 .43 & 19.1219 .12 & 24.7024 .34 & 47.9548 .14 & 549644 & 460404 & 10992 & 17.9412 .15 & 4.894 .96 & 5.385 .50 \\
\hline $\begin{array}{l}\text { Standard } \\
\text { deviation }\end{array}$ & 1.921 .57 & 1.210 .68 & 1.090 .79 & 0.910 .24 & 3281 & 5379 & 1311 & 4.802 .82 & 0.030 .14 & 0.030 .22 \\
\hline Amplitude & 3.823 .12 & 2.421 .21 & 1.921 .58 & 1.600 .48 & 64146 & 95156 & 2519 & 8.404 .91 & 0.050 .24 & 0.050 .42 \\
\hline Maximum & 50.5450 .90 & 20.2719 .91 & 25.3625 .11 & 49.0048 .40 & 581737 & 521475 & 11999 & 19.2214 .47 & 4.915 .04 & 5.405 .68 \\
\hline Minimum & 46.7247 .78 & 17.8518 .70 & 23.4423 .53 & 47.3947 .92 & 517591 & 426319 & 9480 & 10.829 .56 & 4.864 .80 & 5.355 .26 \\
\hline
\end{tabular}

FDM $=$ Fat in Dry Matter 


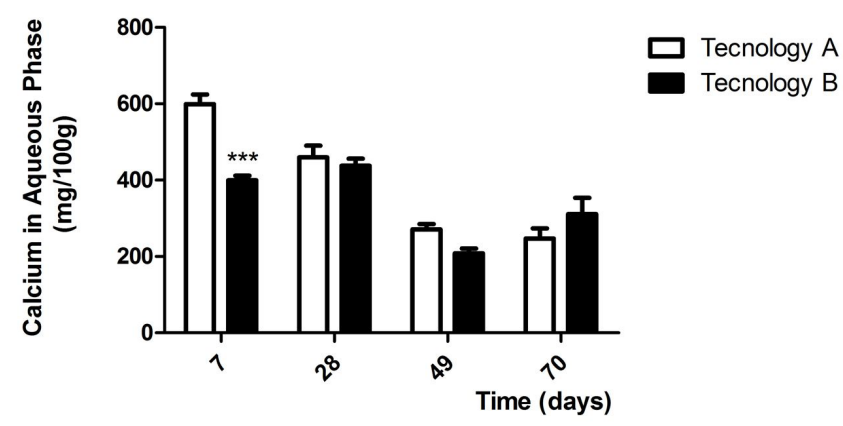

Figure 3. Evolution of calcium in the aqueous phase during cheese ripening for technologies A and B followed by Bonferroni's test $\left.{ }^{* * *} \mathrm{p}<0.001\right)$.

Table 2. Distribution of $\mathrm{pH}$ medium along the ripening of Minas Padrão subject to different technologies (A and $\mathrm{B}$ ) analyzed by the Bonferroni test $(\mathrm{p}<0.05)$.

\begin{tabular}{ccc}
\hline Time (days) & $\begin{array}{c}\text { Calcium in } \\
\text { AP }(\mathrm{mg} / 100 \mathrm{~g}) \\
\text { Technology A }\end{array}$ & $\begin{array}{c}\text { Calcium in } \\
\text { AP }(\mathrm{mg} / 100 \mathrm{~g}) \\
\text { Technology B }\end{array}$ \\
\hline $\mathbf{1}$ & $5.60^{\mathrm{A}}$ & $5.63^{\mathrm{a}}$ \\
$\mathbf{2}$ & $5.07^{\mathrm{B}}$ & $5.30^{\mathrm{b}}$ \\
$\mathbf{7}$ & $5.01^{\mathrm{B}}$ & $5.23^{\mathrm{b}}$ \\
$\mathbf{2 8}$ & $4.89^{\mathrm{B}}$ & $4.96^{\mathrm{C}}$ \\
$\mathbf{4 9}$ & $4.88^{\mathrm{B}}$ & $5.09^{\mathrm{bc}}$ \\
$\mathbf{7 0}$ & $4.99^{\mathrm{B}}$ & $5.03^{\mathrm{c}}$ \\
\hline
\end{tabular}

Means followed by the same letter in the same technology do not differ significantly in the Bonferroni test at $5 \%$ probability.

Table 3. Distribution of calcium content average in the aqueous phase during ripening under different manufacturing technologies (A and $\mathrm{B}$ ) analyzed by the Bonferroni test $(\mathrm{p}<0.05)$.

\begin{tabular}{ccc}
\hline Time (days) & $\begin{array}{c}\text { Calcium in } \\
\text { AP (mg/100 g) } \\
\text { Technology A }\end{array}$ & $\begin{array}{c}\text { Calcium in } \\
\text { PA (mg/100 g) } \\
\text { Technology B }\end{array}$ \\
\hline 7 & $599^{\mathrm{A}}$ & $400^{\mathrm{a}}$ \\
$\mathbf{2 8}$ & $460^{\mathrm{B}}$ & $438^{\mathrm{a}}$ \\
$\mathbf{4 9}$ & $271^{\mathrm{C}}$ & $208^{\mathrm{b}}$ \\
$\mathbf{7 0}$ & $247^{\mathrm{C}}$ & $311^{\mathrm{b}}$ \\
\hline
\end{tabular}

Means followed by the same letter in the same technology do not differ significantly in the Bonferroni test at $5 \%$ probability.

\subsection{Free calcium}

Free calcium is the divalent cation of the mineral present in the AP. Calcium of this nature rises with decreasing $\mathrm{pH}$. Upon analysis of variance was perceived a technology effect on it $(p<0.05)$. There was no significant difference between the ripening times for any of the technologies.

The average free calcium content during the ripening for both technologies, submitted to the two-way analysis of variance and Bonferroni test are shown in Figure 4.

\subsection{Calcium bioaccessibility}

By obtaining the average and the two-way analysis of variance followed by Bonferroni's test (Figure 5) it was also possible to carry out the distribution medium as shown in Table 4 .

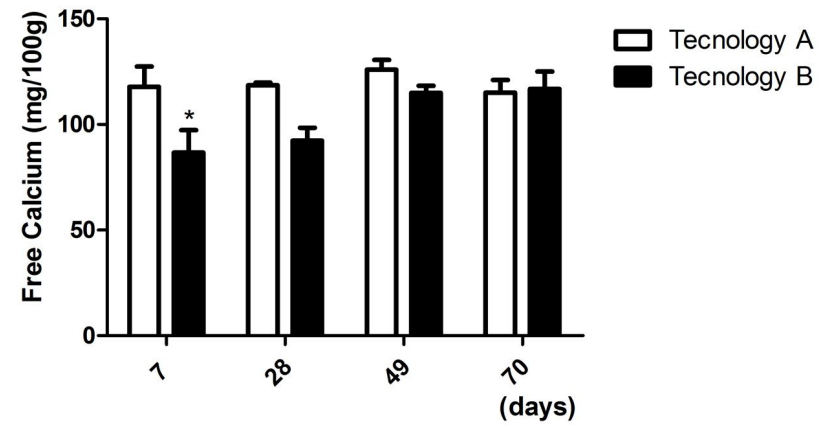

Figure 4. Evolution of free calcium levels along ripening for technologies A and B followed by Bonferroni's test $\left.{ }^{*} \mathrm{p}<0.05\right)$.

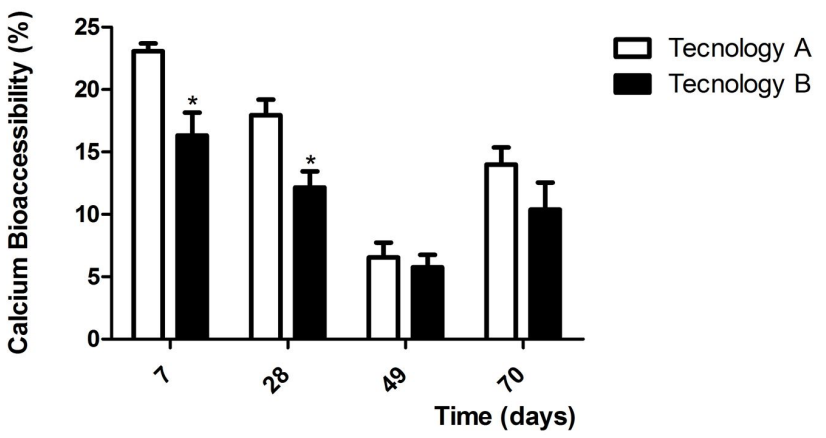

Figure 5. Evolution of calcium bioaccessibility percentages along ripening for technologies A and B followed by Bonferroni's test $\left({ }^{*} \mathrm{p}<0.05\right)$.

Table 4. Average distribution of calcium bioaccessibility percentages along the ripening process under different manufacturing technologies (A and B) analyzed by Bonferroni test $(\mathrm{p}<0.05)$.

\begin{tabular}{ccc}
\hline Time (days) & $\begin{array}{c}\text { Bioaccessibility (\%) } \\
\text { Technology A }\end{array}$ & $\begin{array}{c}\text { Bioaccessibility (\%) } \\
\text { Technology B }\end{array}$ \\
\hline $\mathbf{7}$ & $23.07^{\mathrm{A}}$ & $16.32^{\mathrm{a}}$ \\
$\mathbf{2 8}$ & $17.94^{\mathrm{B}}$ & $12.15^{\mathrm{a}}$ \\
$\mathbf{4 9}$ & $6.56^{\mathrm{C}}$ & $5.75^{\mathrm{b}}$ \\
$\mathbf{7 0}$ & $13.99^{\mathrm{B}}$ & $10.38^{\mathrm{ab}}$ \\
\hline
\end{tabular}

Means followed by the same letter in the same technology do not differ significantly in the Bonferroni test at $5 \%$ probability.

\section{Discussion}

\subsection{Analysis of descriptive statistics of compositional attributes for Minas Padrão cheese produced with different manufacturing technologies}

Although manufactured with different technologies $(A$ and $B)$, the products did not differ significantly $(p>0.05)$ as to the chemical composition attributes of macroconstituents (moisture, protein and total fat), as shown in Table 1.

Manufactured cheeses had similar moisture averages $\left(\mathrm{A}=48.50 \% \mathrm{~m} \cdot \mathrm{m}^{-1}\right.$ and $\left.\mathrm{B}=49.43 \% \mathrm{~m} \cdot \mathrm{m}^{-1}\right)$. FDM had similar mean values between technologies $(47.95 \%$ - A, $48.14 \%$ - B), which is indicative of the experiment control. According to the Codex Standard 283 (World Health Organization, 1978) the two technologies delivered products classified as: soft to firmness 
and full fat (the content of fat in dry matter is above or equal to $45 \%$ and less than $60 \%$ between $45.0 \%$ and $59.9 \%$ ). As to the regulation relating to nutritional information in Brasil (2012) the cheeses produced by both technologies are classified as "high content" of calcium for providing 54.9\% (technology A) and $64.4 \%$ (technology B) of the recommended daily intake for a healthy adult of $1000 \mathrm{mg}$ of calcium per day.

\subsection{Hydrogen potential}

By analyzing Figure 2, it can be seen variation of cheese $\mathrm{pH}$ along the ripening. Technology A resulted in lower $\mathrm{pH}$ means that $B(p<0.01)$ throughout ripening. One possible explanation for this would be the highest level of residual lactose in the cheese, since there was no mass washing during the manufacture. The more lactose distributed in the mass, the greater the fermentation with more lactic acid production and consequently $\mathrm{pH}$ reduction.

It was also observed effect of ripening (Table 2 ) in $\mathrm{pH}$ range $(\mathrm{p}<0.001)$. Upon aging lactose is consumed by the fermenting bacteria NSLAB (Non Starter Latic Acid Bacteria), which results in $\mathrm{pH}$ lowering. The $\mathrm{pH}$ then goes back up again in this experiment by day 49 . This increase can be attributed mainly to proteolysis with the release of ammonia from degradation of cheese proteins into amino acids which are also degraded. The $\mathrm{pH}$ can also be raised by degradation of lactic acid into organic acids and carbon dioxide (El Soda, 1995).

There was a statistically significant difference $(\mathrm{p}<0.001)$ already on the day after manufacture $(\mathrm{A}=5.07$ and $\mathrm{B}=5.30)$ and $(\mathrm{p}<0.05)$ between the study's applied technologies in measurements at day 7 of manufacture $(A=5.01$ and $B=5.23)$ and day 49 of manufacture $(A=4.88$ and $B=5.09)$. The significant difference between the products at day 2 demonstrates the effect of the absence of mass washing in A which in turn let the medium, probably, with high lactose content and high numbers of fermenting bacteria.

Cheese $\mathrm{pH}$ generally has the opposite behavior of the lactose content in the mass. Depending on the type of cheese, it is consumed in about 15 days. In cheese with high lactose content, the $\mathrm{pH}$ may continue to decline for most of its ripening and the primary role of starter bacteria in cheese making is to acidify the cheese milk and lower its $\mathrm{pH}$ by converting lactose found naturally in milk to lactic acid (glycolysis) (Hickey et al., 2015; McSweeney, 2004). However, the increase in $\mathrm{pH}$ is common in various kinds of cheese. This increase may be due to the degradation process of lactic acid present in the mass of cheese along with proteolysis, hence, the release of ammonia from the amino acid degradation (Gobbetti et al., 2015; Fox et al., 2000). Such proteolysis is favored by high moisture content in Minas Padrão cheese.

In this study, $\mathrm{pH}$ lowering had taken place until day 30 . Assumptions about such a result can be raised. Once it is a non-LD cheese type and has high moisture content, Minas Padrão cheese has significant residual content of citric acid, extending the $\mathrm{pH}$ lowering time.
During cheese production most of the lactose is lost in whey, but residual lactose stays with cheese. The amount of residual lactose is affected by processing parameters, presence of starter and nonstarter lactic acid bacteria, could be determined by different methods to avoid fermentation during ripening, leading to modifications in cheese identity (Monti et al., 2017; Biswas et al., 2015; Lee et al., 2014; Sheehan et al., 2007; Upreti et al., 2006).

\subsection{Aqueous phase calcium}

A slight increase in total calcium content in technology B was observed (Table 1). This is probably linked to $\mathrm{pH}$ which in that technology is slightly increased. The lower the $\mathrm{pH}$, the higher the demineralization of cheese and therefore a larger amount of calcium can migrate to whey already in the manufacturing process (McSweeney, 2004; Fox et al., 2000).

By analyzing the AP calcium against the total calcium to technologies A and B, it was found that $83.65 \%$ of the calcium was present in AP for cheese produced in A, and $19.79 \%$ of the total calcium as free calcium. In B, $62.82 \%$ of the mineral was in the AP, and $14.34 \%$ of the total calcium as free calcium, which can be explained by the lower $\mathrm{pH}$ value, even though significantly lower in $\mathrm{A}(\mathrm{A}=4.83$ and $\mathrm{B}=4.96)$.

Analyzing calcium content in APs over time (Figure 3 ) there was a certain direct relationship with $\mathrm{pH}$ once during ripening the $\mathrm{pH}$ decreases and so does the calcium content in the AP. However, by evaluating the calcium content in the AP between technologies, it has been noticed a higher content in A where the $\mathrm{pH}$ was lower. The technological effect result $(\mathrm{p}<0.01)$ occurred due to the higher solubility of calcium since cheese has lower $\mathrm{pH}$, the so-called demineralization effect. Considering the effect of time ( $\mathrm{p}<0.001)$, as shown in Table 3 , it is clear that calcium content in AP is decreased. This is possibly due to proteolysis during ripening and protein breaking into smaller fragments. The break-down of a large fragment into several smaller fragments destabilizes the balance of calcium distribution in cheese. Calcium transferred to AP is important for stabilization of formed peptides pushing down the water, which has a role in stabilization of solvating the formed peptides. The pressure for the extraction of cheese AP is not sufficient to physically remove this layer off the cheese mass.

The significant difference between the tested technologies $A$ and $B$ is mostly noticed at day $7(p<0.001)$ which averaged calcium content in AP $599 \mathrm{mg} \cdot 100 \mathrm{~g}^{-1}$ (A) and $400 \mathrm{mg} \cdot 100 \mathrm{~g}^{-1}(\mathrm{~B})$. For technology $\mathrm{A}$ it has been observed higher average calcium content in AP than in B during the first measurement (at day 7) as a result of demineralization, which lessens during ripening.

Calcium levels in AP for technology B decreases significantly $(\mathrm{p}<0.001)$ between day $28\left(438 \mathrm{mg} \cdot 100 \mathrm{~g} \mathrm{~g}^{-1}\right)$ and day $49\left(208 \mathrm{mg} \cdot 100 \mathrm{~g}^{-1}\right)$, with no significant difference in other measurements (days). In $\mathrm{A}$, it has been noticed differences at day $7\left(599 \mathrm{mg} \cdot 100 \mathrm{~g}^{-1}\right)$ and day $28\left(460 \mathrm{mg} \cdot 100 \mathrm{~g}^{-1}\right)(\mathrm{p}<0.01)$ and again day $28\left(460 \mathrm{mg} \cdot 100 \mathrm{~g}^{-1}\right)$ and day 49 day $\left(271 \mathrm{mg} \cdot 100 \mathrm{~g}^{-1}\right)$ $(\mathrm{p}<0.001)$, stabilizing thereafter. 


\subsection{Free calcium}

Free calcium levels for both technologies present statistically significant difference $(\mathrm{p}<0.05)$ (Figure 4$)$ being noticeable at day 7 which averaged free calcium content of $118 \mathrm{mg} \cdot 100 \mathrm{~g}^{-1}$ of AP (A) and $87 \mathrm{mg} \cdot 100 \mathrm{~g}^{-1}$ of AP (B). In technology A, it was observed higher averages for free calcium than in B. In A, it was also observed less variation of free calcium content throughout ripening, probably because of the first measurement (day 7) where the free calcium content was already high.

\subsection{Calcium bioaccessibility}

The results for determination of calcium bioaccessibility in technologies A and B are as follows (Table 1): 17.94\% and 12.15\%, with standard deviation 2.82 and 4.80, respectively. Although the $\mathrm{pH}$ is lower in $\mathrm{A}$, it showed higher bioaccessibility of calcium than in $\mathrm{B}$. That may be due to the higher calcium content in the AP in A $\left(\mathrm{A}=460 \mathrm{mg} \cdot 100 \mathrm{~g}^{-1}\right.$ and $\left.\mathrm{B}=404 \mathrm{mg} \cdot 100 \mathrm{~g}^{-1}\right)$, resulting from greater demineralisation caused by $\mathrm{pH}$ effects, even though the total calcium content in $B$ is greater than in A $\left(\mathrm{A}=549 \mathrm{mg} \cdot 100 \mathrm{~g}^{-1}\right.$ and $\left.\mathrm{B}=644 \mathrm{mg} \cdot 100 \mathrm{~g}^{-1}\right)$.

There was constant variation in bioaccessibility along the ripening. Upon the completion of the analysis of variance was perceived the effect of technology $(p<0.001)$, as shown in Figure 5. The experiments in A showed higher average percentage of calcium bioaccessibility than in B due to several factors, such as calcium in the AP and free calcium which are coordinated primarily by changes in $\mathrm{pH}$. It was also observed effect of ripening time $(\mathrm{p}<0.001)$ in the variation of the percentage of calcium biovailability (Table 4). As ripening advances, $\mathrm{pH}$ is lowered thus reducing the mineral bioaccessibility in cheese. The calcium content in AP also decreased in the early stages of ripening that in turn impacting negatively on calcium bioaccessibility. The elevation of $\mathrm{pH}$ in the final phase of ripening gives rise to bioaccessibility which is also influenced by the substantial rise in calcium content in AP. There was a significant difference $(p<0.05)$ concerning the effect of technologies in the early stages of ripening. In the measurement performed at day 7 of manufacturing calcium bioaccessibility values were $23.07 \%$ in A and $16.32 \%$ in B. At day 28 of manufacturing the average results were $17.94 \%$ for mineral bioaccessibility in A and $12.15 \%$ in $\mathrm{B}$.

Van Dokkum et al. (1996), when controlling women 's diet with groups consuming fresh cheese for a calcium bioavailability study, found higher results for bioavailability than the ones in this study. The findings showed that $37.7 \%$ of ingested calcium was bioavailable.

Minas Standard cheese has a ripening period to improve flavor and texture in which different microorganisms plays important roles for the Brazilian cheese identity (Bemfeito et al., 2016; Nepomuceno et al., 2016; Cardoso et al., 2015). However, from a nutritional point of view, especially for Minas Standard cheese as a source of calcium, it would be more appropriate the consumption of the fresh cheese, since the findings of this study point out to $23.07 \%$ mineral bioaccessibility in the initial seven days of manufacture. All subsequent measurements showed a decrease in the average calcium bioaccessibility $(\mathrm{p}<0.05$ and $\mathrm{p}<0.001$ respectively) and averaged $17.94 \%$ after
28 days and $6.56 \%$ at 49 days old, rising again $(\mathrm{p}<0.05)$ in the last measurement period of the study at day 70 (13.99\%), a fact that is confirmed by the slight increase observed in $\mathrm{pH}$.

As to technology $\mathrm{B}$ it has been determined that $16.32 \%$ of the mineral was bioavailable at seven days of manufacture, value which is not statistically different $(p>0.05)$ from the average determined at 28 days (12.15\%). In the determination of bioaccessibility at 49 days, it was noted a significant decrease $(p<0.05)$ that averaged 5.75. The last measurement for calcium bioaccessibility was high at $10.38 \%$, also consistent with the slight rise in $\mathrm{pH}$ at this stage of ripening. The relationship between calcium bioaccessibility and cheese ripening time is a relevant factor, it is little explored by the scientific community, though. Nutritional aspects of foods determine preferences of consumption and the development of dairy products as cheeses. Cheeses are recognized as a calcium source but the discussions of calcium bioaccessibility are not frequency in the industry. Changes in the cheese matrix during ripening affect the bioaccessibility of calcium in Minas Padrão cheese. Dairy industries could apply the results of this research during the development of new products and inform to consumers the best time to consume cheese based on calcium bioaccessibility. The results obtained in this study promote a discussion: Minas Standard cheese as calcium source, its sensory aspects and even cultural aspects related to the Brazilian way of consumption of the cheese. Such studies are important for improving the technologies not only for cheese and dairy but also for various sectors of the food industry, hence requiring greater interaction between nutritional and technological aspects of product development.

\section{Conclusions}

During ripening, variations in calcium partition, calcium content in AP and dissociation of the mineral in AP occurred and these changes are linked to physicochemical and biochemical changes particularly with respect to $\mathrm{pH}$ variations.

Calcium bioaccessibility decreases during cheese ripening, regardless of the tested technology, due to the lowering of $\mathrm{pH}$ and calcium content in AP then rising again in the final phase of ripening period. Taking into consideration the time of ripening, it can be said, from a nutritional point of view, the highest bioaccessibility of calcium is found in the initial phase (up to seven days) and in the final stage (about 70 days) of ripening, although, sensorial and historically, it is consumed a bit older than 20 days of ripening. At the same day of measurement, comparing the two technologies, it became clear that the bioaccessibility was higher in technology A.

The lack of a specific legislation for Minas Standard cheese contributes to a large variability in the composition of this cheese, affecting its identity and its indication as a food source of calcium in diet, since this variation interferes with calcium bioaccessibility and, therefore, the calculation of food portions to supply for the correct daily needs of this nutrient.

The results obtained in this work hopefully may allow further studies and the development of products in which calcium bioaccessibility might be indicated on the product's label accordingly to its ripening time. 


\section{Acknowledgements}

To FAPEMIG, CNPq, Embrapa/Monsanto and Professional Master's in Science and Technology of Milk and Dairy Products/UFJF for financial and technical support. MFM and ITP are recipients of fellowship from CNPq.

\section{References}

Bemfeito, R. M., Rodrigues, J. F., Silva, J. G., \& Abreu, L. R. (2016). Temporal dominance of sensations sensory profile and drivers of liking of artisanal Minas cheese produced in the region of Serra da Canastra, Brazil. Journal of Dairy Science, 99(10), 7886-7897. http:// dx.doi.org/10.3168/jds.2016-11056. PMid:27497904.

Biswas, A. C., Muthukumarappan, K., Marella, C., \& Metzger, L. E. (2015). Understanding the role of natural cheese calcium and phosphorous content, residual lactose and salt-in-moisture content on block-type processed cheese functional properties: cheese hardness and flowability/meltability. International Journal of Dairy Technology, 68(1), 44-53. http://dx.doi.org/10.1111/1471-0307.12167.

Brasil, Agência Nacional de Vigilância Sanitária. (2012, November 13). Dispõe sobre o regulamento técnico sobre informação nutricional complementar (Resolução da Diretoria Colegiada no 54, de 12 de novembro de 2012). Diário Oficial [da] República Federativa do Brasil. Retrieved from http://portal.anvisa.gov.br/documents/html

Brasil, Ministério da Agricultura, Pecuária e Abastecimento. (2017, March 30). Dispõe sobre o regulamento da inspeção industrial e sanitária de produtos de origem animal (Decreto no 9.013, de 29 de março de 2017). 2012). Diário Oficial [da] República Federativa do Brasil.

Cardoso, V. M., Borelli, B. M., Lara, C. A., Soares, M. A., Pataro, C., Bodevan, E. C., \& Rosa, C. A. (2015). The influence of seasons and ripening time on yeast communities of a traditional Brazilian cheese. Food Research International, 69, 331-340. http://dx.doi.org/10.1016/j. foodres.2014.12.040.

Cozzolino, S. M. F. (2010). Biodisponibilidade de nutrientes (pp. 12-54). São Paulo: Manole.

El Soda, M. (1995). Acceleration of flavor formation during cheese ripening. Developments in Food Science, 37, 721-746. http://dx.doi. org/10.1016/S0167-4501(06)80192-5.

Fernández-García, E., Carvajal-Lérida, I., \& Pérez-Gálvez, A. (2009). In vitro bioaccessibility assessment as a prediction tool of nutritional efficiency. Nutrition Research, 29(11), 751-760. http://dx.doi. org/10.1016/j.nutres.2009.09.016. PMid:19932863.

Fox, P. F., Timothy, P. G., Timothy, M. C., \& McSweeney, P. L. H. (2000). Fundamentals of cheese science (pp. 750-760). Maryland: Aspen Publication.

Gobbetti, M., De Angelis, M., Di Cagno, R., Mancini, L., \& Fox, P. F. (2015). Pros and cons for using non-starter lactic acid bacteria (NSLAB) as secondary/adjunct starters for cheese ripening. Trends in Food Science \& Technology, 45(2), 167-178. http://dx.doi. org/10.1016/j.tifs.2015.07.016.

Gropper, S. S., Smith, J. L., \& Groff, J. L. (2013). Advanced nutrition and human metabolism (6th ed.). Belmont: Thomson Wadsworth.

Hickey, C. D., Auty, M A E., Wilkinson, M. G., \& Sheehan, J. J. (2015). The influence of cheese manufacture parameters on cheese microstructure, microbial localisation and their interactions during ripening: a review. Trends in Food Science \& Technology, 41(2), 135148. http://dx.doi.org/10.1016/j.tifs.2014.10.006.

Johnson, M. E. (2017). A 100-year review: cheese production and quality. Journal of Dairy Science, 100(12), 9952-9965. http://dx.doi. org/10.3168/jds.2017-12979. PMid:29153182.
Lee, H., Rankin, S. A., Fonseca, L. M., \& Milani, F. X. (2014). Lactose and galactose content in cheese results in overestimation of moisture by vacuum oven and microwave methods. Journal of Dairy Science, 97(5), 2567-2577. http://dx.doi.org/10.3168/jds.2013-7522. PMid:24630670.

Luten, J., Crews, H., Flynn, A., Van Dael, P., Kastenmayer, P., Hurrell, R., Deelstra, H., Shen, L.-H., Fairweather-Tait, S., Hickson, K., Farré, R., Schlemmer, U., \& Frøhlich, W. (1996). Interlaboratory trial on the determination of the in vitro iron dialysability from food. Journal of the Science of Food and Agriculture, 72(4), 415-424. http://dx.doi.org/10.1002/(SICI)1097-0010(199612)72:4<415::AIDJSFA675>3.0.CO;2-X.

Martini, L., \& Wood, R. J. (2002). Relative bioavailability of calciumrich dietary sources in the elderly. The American Journal of Clinical Nutrition, 76(6), 1345-1350. http://dx.doi.org/10.1093/ajcn/76.6.1345. PMid:12450902.

McSweeney, P. L. (2004). Biochemistry of cheese ripening. International Journal of Dairy Technology, 57(2-3), 127-144. http://dx.doi. org/10.1111/j.1471-0307.2004.00147.x.

Monti, L., Negri, S., Meucci, A., Stroppa, A., Galli, A., \& Contarini, G. (2017). Lactose, galactose and glucose determination in naturally "lactose free" hard cheese: HPAEC-PAD method validation. Food Chemistry, 220, 18-24. http://dx.doi.org/10.1016/j.foodchem.2016.09.185. PMid:27855887.

Nepomuceno, R. S. A. C., Costa, L. C. G. Jr., \& Costa, R. G. B. (2016). Exopolysaccharide-producing culture in the manufacture of Prato cheese. Lebensmittel-Wissenschaft + Technologie, 72, 383-389. http:// dx.doi.org/10.1016/j.lwt.2016.04.053.

Pereira, J. P. F., Campos, N. S., Oliveira, A. M. F., Sousa, R. A., Paula, J. C. J., \& Silva, P. H. F. (2018). Determinação da composição, partição e bioacessibilidade de cálcio em queijos Minas Padrão comerciais. Revista do Instituto de Latícinios Cândido Tostes, 73, 1-6.

Pimentel, L. S., Moraes, J., Luna, A. S., Barros, D. B., Pimentel, T. C., Guimarães, J. T., Silva, H. L. A., Balthazar, C. F., Esmerino, E. A., Freitas, M. Q., Ranadheera, C. S., Silva, M. C., Quitério, S. L., Raices, R. S. L., \& Cruz, A. G. (2018). Brazilian infant dairy foods: mineral content and daily intake contribution. British Food Research, 120(10), 2454-2465. http://dx.doi.org/10.1108/BFJ-11-2017-0649.

Salvat-Brunaud, D., Maubois, J. L., Le Graët, Y., Piot, M., Maillard, M. B., Corre, C., \& Thierry, A. (1995). Extraction et analyse de la phase aqueuse de l'emmental à 4 stades d'affinage. Le Lait, 75(3), 239-249. http://dx.doi.org/10.1051/lait:1995316.

Santiago-López, L., Aguilar-Toalá, J. E., Hernández-Mendoza, A., Vallejo-Cordoba, B., Liceaga, A. M., \& González-Córdova, A. F. (2018). Bioactive compounds produced during cheese ripening and health effects associated with aged cheese consumption. Journal of Dairy Science, 101(5), 3742-3757. http://dx.doi.org/10.3168/ jds.2017-13465. PMid:29477517.

Sheehan, J. J., Fenelon, M. A., Wilkinson, M. G., \& McSweeney, P. L. (2007). Effect of cook temperature on starter and non-starter lactic acid bacteria viability, cheese composition and ripening indices of a semi-hard cheese manufactured using thermophilic cultures. International Dairy Journal, 17(6), 704-716. http://dx.doi. org/10.1016/j.idairyj.2006.08.011.

Silva, H. L. A., Balthazar, C. F., Esmerino, E. A., Vieira, A. H., Cappato, L. P., Parente, R. No., Verruckd, S., Cavalcanti, R. N., Portela, J. B., Andrade, M. M., Moraes, J., Franco, R. M., Tavares, M. I. B., Prudencio, E. S., Freitas, Q. M., Nascimento, J. S., Silva, M. C., Raices, R. S. L., \& Cruz, A. G. (2017). Effect of sodium reduction and flavor enhancer addition on probiotic Prato cheese processing. Food Research International, 99(Pt 1), 247-255. http://dx.doi.org/10.1016/j. foodres.2017.05.018. PMid:28784481. 
Upreti, P., McKay, L. L., \& Metzger, L. E. (2006). Influence of calcium and phosphorus, lactose, and salt-to-moisture ratio on Cheddar cheese quality: changes in residual sugars and water-soluble organic acids during ripening. Journal of Dairy Science, 89(2), 429-443. http://dx.doi.org/10.3168/jds.S0022-0302(06)72107-5. PMid:16428613.

Van Dokkum, W., De La Gueronniere, V., Schaafsma, G., Bouley, C., Luten, J., \& Latge, C. (1996). Bioavailability of calcium of fresh cheeses, enteral food and mineral water: a study with stable calcium isotopes in young adult women. British Journal of Nutrition, 75(6), 893-903. PMid:8774234.

Walther, B., Schmid, A., Sieber, R., \& Wehrmuller, K. (2008). Cheese in nutrition and health. Dairy Science \& Technology, 88(4-5), 389-405. http://dx.doi.org/10.1051/dst:2008012.

World Health Organization, Food and Agriculture Organization of the United Nations. (1978). Codex general standard for cheese 283. In Joint FAO/WHO Food Standards Programme, Codex Alimentarius: milk and milk products. Rome. 